\title{
Kamping Yeri İşletene Otelcinin Eşyanun Telef, Hasar ve Çalınmasından Mes'uliyeti Esaslarn Uygulanabilir Mi?
}

\author{
Doç. Dr. Nuşin AYITER \\ 1 - Otelcilik Mukavelesi :
}

Türkiyede turist sayısının artmasıyla, kamping yeri işletenlerin turistlerin mal ve can emniyetinden dolays mes'uliyetleri meselesi aktüel bir mahiyet alacaktır. Doğmakta olan bir problem hakkında söz söylemek için henüz erken olduğu düşünülebilirse de, yakında mahkemelerin uğraşmak mecburiyetinde kalacakları kanaatinde olduğumuz bu meseleyi şimdiden incelemek istiyoruz.

Kamping yeri işletenlerin, yolcunun beraberinde getirdikleri eşyanın telef, hasar ve çalınmasından mes'uliyetleri ilk bakıșta BK. 478 ve dev. gereğince otelci ve hanciların mes'uliyetine dahil telakki olunabilir. Fakat bu peşin hükmü vermeden otelci, hancı garaj işletenler gibi mefhumlar kar\$sısında kamping yeri işletmesinin mahiyetini tayin etmek gerekir. BK. 478 de hükme bağlanan sert kanunî sebep mes'uliyetinin mesnedi bir otel işletmesine otel misafiri (müşteri) kabul etmekten doğan münasebettir (1). Bu münasebete otel müșterisi kabul etme münasebeti (Gastaufnahmeverhaltris) denebilir. Müşteri kabul etme ile meydana gelen münasebet kaideten otel müșterisi ile otelci arasında meydana gelen bir akdi münasebettir (Gastaufnahmevertrag). Bu münasebetten müteaddit hak ve borçlar doğar. Binaenaleyh otelcilik akdi (2) bakımından önemli bir mesele, akitte mündemiç olan bütün bu münasebetleri tek bir akdi münasebetten doğan borçlar ve haklar olarak mi, yoksa muhtelit bir akitteki akdi münasebetlerden ayrı ayn doğan hak ve borçlar olarak mi kabul etmek gerektiğidir. BK. na müiteallik umumi eserlerde, otelcilik akdi daima muhtelit

(1) Zahit Imre: Otel, han, ahır ve garaj işletenlerin mes'uliyeti Tahir Taner'e Armağan Istanbul 1956 sh. 192.

(2) Oser-Schönenberger: art 487 No: 8 ve dev. 
bir akit olarak tavsif olunmuştur (3). Fakat akit tiplerinden hiç birinin hükümleri olduğu gibi otelcilik mukavelesine tatbik edilemediğinden, doğrusu Federal mahkemenin bir kararında ifade edildiği üzere, bu mukaveleyi "otelcinin bir müșteriyi müessesesine kabul etmekle inikad eden nevi şahstna münhastr bir akit" addedmektir (4). Otelcilik mukavelesinin muhtevasın tayin her münferit hadisede güçlük arzeder. Çünki bu muhteva üzerinde taraflar çok defa sarih bir şekilde anlaşmaya varamazlar. Otelcilik sanayii nin bilhassa turizmin inkişâfmndan ne derece etkilendiği malûmdur. Bu etkileniş kendisini en lüks otellerden, alelâde ihtiyaçların yaz mevsiminde en ucuz bir şekilde tatmin edildiği ișletmelerin sayllarmın artmasında göstermektedir. Hele son inkișâf, artık otel denince asgari unsur saylan bir binanın mevcudiyeti gereğini de kaldırmıș kütlelerin gezmek, görmek ihtiyaçlanın karşılamak üzere büyük toprak sahalarının çadırlarıyla, yahut arabaları ile gelenlere tahsis edilmesi demek olan kamping meydanları işletmelerini ortaya çıkarmıştır. Acaba borçlar kanununun 478 ve dev. maddelerinde bu fevkalâde değişik hallere uygulanacak kadar elâstikiyet var mıdrr? Acaba bir kamping yerine gelen turist ile kamping ișletmesi arasinda bir otelcilik mukavelesi yahut bir barmdırma mukavelesi (Beherbergungsvertrag) bulunduğu söylenebilir mi ?

En umumi manâda bir otelcilik mukavelesinin bulunması için şu şartlar aranır :

1 - Bartndirmanin temini: Barındirmadan (Beherbergung) bahsedilebilmesi için asgari bir barmulacak ye: bulunması gerekir. Barınılacak yer dendiği zaman lüks bir otelden, hana kadar hatta muvakkaten kurulabilecek çadır, baraka kabilinden bir yer anlaşı. ur. Barmılacak yer, bir şahsın muvakkat bir zaman için ev (home, Heim,) yerine kullandığı bir ersatzdır (5). Barınlacak yer insamın asıl yașadı̆̆ı yerin muvakkat ersatzıdır dendiğine göre, burada insanın asgari ihtiyaçlarının da barınağı işleten tarafından temini gerekir. Asgari ihtiyaçların temini için ise hiç olmazsa müşteriye kapalı bir yer tahsis edilmis olmalıdır. Yerin kapalı olması demek, mutlaka sabit bir bina olması demek değildir. Salaş baraka, çadır

(3) BiIge N.: Borçlar hukuku dersleri Sh. 310; Oser-Schönenberger, art 487 No: 10; Buchli Die Haftung der Gast und Stallwirte, Bern 1932 , Sh. 13 ve dev. Imre; Z: agy. Sh. 192.

(4) FMK 71 II 114; Michel R. Der Gastaufnahmevertrag Zürich 1957 Sh. 17.

5) Michel, age. Sh. 25. 
temini dahi barmak temini sayılabilir. Fakat barınak temininin, müşteri kabul etme çerçevesinde mütalâa edilebilmesi için bazı şartlar aranır.

$a-B a r$ nak temini bir zenaatın icrast icabı (Gewerbsmässig) olmaltdtr (6). Seyahat edenlerin zaman zaman ivaz mukabilinde de olsa kabul edilmesi bir otelcilik akdi sayllamaz. Meselâ turist akınının çok olduğu devrelerde, hususî evlerin odalarına otellerde yer bulamayan turistlerin kabulü barmak ieminidir fakat otel. cilik mukavelesi değildir. Çünki bu halde oda, mobilya, sıhhi tesisat v.s. müşteri kabulü gayesine tahsis edilmiş olmayıp, müșterinin bunlardan istifadesi zenaatın icrası hudutlam içinde olmamak. ta fakat tesadüfi ve istisnaî bir mahiyet taşımaktadır. Nitekim Al. man MK. § 701 zenaat olarak işletmeyi, otelcinin getirilen eşyanın hasarı, telef olması ve çalınmasından mes'uliyetinin \$artı olarak kabul etmektedir (7).

$b$ - Herkese açtk olmak: Bununla kastedilen işletmenin her müracaat edene barınak temin etmesidir. Otele kabul edilme muayyen bazı şartlara bağlanabilir. Ona mukabil bir cemiyet tarafından işletilen ve yalnız o cemiyetin azasına tahsis edilen bir ișletme, herkese açık bir otel sayılamaz (8).

Barınak teminini tazammun etmekle beraber bazı mukaveleler otelcilik mukavelesi saylamazlar. Ezcümle hastahane, sanatoryumlar, kaplıcalar kaideten otel değillerdir. Mamafih bazı hallerde kür yerlerindeki otellerde olduğu gibi tedavi ve nekahat gayesi ile müşteri alan bir müessese, bir otel işletmesinin hususiyetlerini taşıyabilir ve sadece hastalara tahsis edilmiş olmayabilir. Talebe yurtları, enstitüler, leyli mekteplerde de barınak temini otelcilik mukavelesini tazammun etmez. Pansiyonlar bakımından durum münakaşalıdır. Otel ișletmeleri ile benzerlik gösteren pansiyonlarda, pansiyon sahibinin mes'uliyetini kabul etmemek doğru olmaz. Ona mukabil devamlı bazı hizmetler ve yemek yemekle müterafik uzun süreli kira akdinin kabul edilmesinin ahval ve şeraite daha uygun düşeceği bir münasebette, pansiyoncunun BK. 478 uyarınca mes'ul olmayacığını kabul etmek daha doğru olur. Şu halde aradaki münasebetin mahiyetini dolayısıyla BK. 478 deki mes'uliye-

(6) Michel, age. Sh. 26, İmre agy. Sh. 194.

(7) Staudinger $\$ 701$, not 6 , a.

(8) Michel agy, sh. 27. 
tin şartlarının bulunup bulunmadığını tayin hususunda hâkime takdir yetkisi bırakılmaktadır (9).

Diğer bir münakașal 1 mesele de yataklı vagon işletmeleriyle yolcu arasındaki bir münasebetin otelcilik akdi telaki edilebilip edilemiyeceğidir. Eğer öyle ise, yataklı vagon işletmesi, yolcuların seyahat bagajlarının kaybindan, hasara uğramasından, telef olmasından kusur aranmaksızm azami bir hududa kadar mes'ul olacaklardrr. Bu hususta İtalyan MK. 1783-1786 hükümlerinde kür müesseseleri, eğlence mahalleri, plaj tesisleri pansiyonlar, lokantalar, yataklı vagon ve benzerleri ișletmelerinin hususi mes'uliyete tabi oldukları sarahaten ifade edilmiştir. Italyan MK.' nun bu görüşï Roma hukukundan gelmektedir. Çünki Roma hukukunda gemicinin mes'uliycti ahır ve han sahiplerinin mes'uliyeti gibidir. Bu se. bep mes'uliyetinin mesnedi umuma açı bir yere muvakkaten giden kimsenin mallarmm tehlikeye maruz bulunmasidrr. Türk hukuku bakımından Zahit Imre Temyiz mahkemesinin BK 478 deki mes'uliyeti hamamlara teşmil eden bir kararına dayanarak mes'uliyetin evlcviyetle yataklı vagon ve gemilere de teșmil edilmesi gerektiği fikrindedir. Fakat müellif doğrudan doğruya temyiz mahkemesinin bu içtihadına itiraz etmekte kanunda bu hususta bir sarahat bulunmadıkça BK. 478 hükmünün hamamlara tatbikini yanlış bulmaktadır (10). Bu kanaate biz de katılıyoruz. Çïnki yatakli vagonlar uzun mesafeler için yapılmıș olan nakliye mukaveleleri çerçevesinde, yolcunun istirahatini temin ederler. Binaenaleyh bu halde barınak temini aslî gaye değjldir. Saniyen bir oteldeki mes'uliyet, yataklı vagonlardaki tehlikenin fazlalı̆̆ı dolayısıyla kanunda sarahat olmadıkça yataklı vagona tatbik edilmemelidir. Nihayet șartları varsa istihdam edenin mes'uliyeti, bina, imal olunan șeylerden dolayı mes'uliyet, yahut ifa yardımcılarından dolayı mes'uliyet esaslarının tatbiki (aksi halde mes'uliyetin azamî hudu. dunun $100 \mathrm{TL}$. olduğu düşünülürse) yolcu için zaten daha müsait olduğundan yolcu, işletmenin mes'uliyetini tazammun eden hükümden istifade etmemeyi tercih edecektir. Alman hukukunda da yataklı vagonların otel sayılamıyacağı görüşü hâkimdir (11).

? - Otel hizmetlerinin bulunmast; otel mukavelesi çerçevesinde en iptidaî barındırma șeklinde dahi asgarî bir hizmetin mevcut olması gerekir. Bu da hiç olmazsa barmılacak yerin gösteril-

(9) Imre, Z.: agy, Sh. 195.

(10) Imre, Z.: agy, Sh. 195, Tandoğan H., Otelcilerin mes'uliyeti AHF. Dergisi, C. XII, Sh. 3-4, Sh. 201 ve dev.

(11) Staudinger, Kommentar zum BGB, § 701, not 9. 
mesi ve zarurî temizliğinin yapılmasıdır (12). Otel mukavelesinin mahiyetinde mündemiç bulunan hizmet edimlerinin bittabi işletmenin sınıfına göre artması ve kalitesinin yükselmesi lâzımdır.

II - Otelcilik mukavelesi karşıstnda, kamping yeri işletenle, oraya gelen turist arasindaki münasebetin tavsifi :

Otelcllik mukavelesinin iki șartı olan barındırma ve asgari hizmet edimi bazı hallerde kamping yeri tahsisinde mevcuttur. Bunun için iki hali ayrı ayrı göz önüne almak gerekir.

1 - Umumiyetle kamping yerine turist kendi çadırıyla veya gece içinde yatmaya, ufak tefek pişirmeye, çamaşır yıkamaya, shhhi ihtiyaçları görmeye elverişli bir römorklu vasıta ile gelir. Bu halde kamping yerinde çadırın kuracak veya römorklu vasıtasımı çekecek bir yerin kendisine tahsisi kanaatimce bir otelcilik mukavelesini tazammun etmez. Çünki burada kamping yerinin sahibi, mükavelenin asgari unsurlarından biri olan asgari hizmet edimini çadrra veya barakaya (hatta bazen içinde uyumaya mahsus torbaya "Sac à Couchage») yer göstermekle yerine getirmekte fakat barındırma işini üzerine almamaktadır. Burada barınma işini turist bizzat temin ettiği için bir otelcilik mukavelesinden bahsolunamaz. Kanaatimce bu halde sadece toprak parçasının ufak bir kısmıla umumi musluk gibi bazı șeylerin kullanılmasi hususunda kira akdi söz konusu olabilir ve kamping sahibi ile turist arasındaki akdî münasebet kiranın hususî bir nevi saylabilir. Nitekim yeni bir Alman içtihadında (13) hulâsaten şunlar ifade edilmektedir. "Otelcinin mes'uliyetinin mesnedi, böyle bir zararın meydana gelmesindeki odalarn durumu, kilitlenmeleri, müstahdemlerin ve müșterilerin seçilmesi gibi hususlarnn zenaatı icra edenin hâkimiyet sahası içinde bulunmasındadır. Halbuki bir kamping mukavelesinde, işletmenin sahibi sadece bir yer ve umumi tesisleri emre amade kllar, geri kalan her husus gelenin kendisine kalır. Kamping yeri sahibinin BGB § 537 ve 538'e göre mes'uliyeti de kabul edilemez. Gerçi kamping mukavelesi kira akdi ile mühim bir benzerlik gös. termektedir. Çünki onun da muhtevası bazı şeylerin kullanılmasımın ivaz karşılığında karşı âkide terkedilmesidir. Fakat diğer taraftan kamping mukavelesi normal bir kira akdi karşısırida o kadar önemli hususiyetler taşır $\mathbf{k i}$, kiracının mes'uliyetini sertleştiren hükümler ancak çok dikkatli davranmak şartıyla kamping sahibine

(12) Michel, age. Sh. 34 .

(13) OLG Koblenz, 24.5.1966 (NJW 1966 Sh. 2017). 
tatbik olunabilirler. Meselâ bir misafirin kamping sahasındaki inşa hatalarından dolayı zarara uğraması halinde kamping sahibinin mes'uliyeti kabul edilmiştir». Türk Hukuku bakımından da aynı görüs kabul edilebilir. Ayrıca kamping sahasirin sahibi, turistin mallarına veya șahsına gelen zarardan, eğer şartları varsa bina ve imal eserinin maliki sıfatıyla, yahut MK. 656 ya göre gayrımenkul maliki sifatıyla mes'ul olur. Nitekim Koblenz OLG, mezkûr kararında bir turistin üzerine çürük bir ağaç dalının yıkılması üzerine meydana gelen zararın mahiyeti ile de meşgul olmaktadır.

Bir kamping yerinde, kamping işletmesi tarafindan bekçi bulundurulması halinde acaba esyanın uğradı̆̆ zarardan kamping idaresi BK. 478 uyarinca mes'ul olur mu sualine de menfi cevap vermek gerekir. Kamping yerinde bekçi bulundurulması kamping idaresinin arzettiği bir hizmettir. Bekçinin bulundurulması turist ile kamping idaresi arasındaki kira akdi olarak nitelendirilebilen aktin mahiyetini değiștirip onu barınak teminini tazammun eden bir akit haline getiremez. Ancak bu halde kamping idaresi bulundurulacağ taahhüt edilen bekçinin bulundurulmamasindan BK. 96 ve dev, bekçinin haksız fiilinden BK. 55, bekçinin vazifesini ifa esnasinda meydana gelen zarardan BK $100^{\prime}$ e göre, yani her halde umumi hükümlere göre mes'ul olur.

Kendi yatacak yeri ile gelen turistin kıymetli eşyasını idareye teslim etmesi halinde alelade bir vedia akdi meydana gelir. Bu eș. yanın ziyaundan kamping idaresi vedia alan sıfatıyla mes'ul olur. Turistin motorlu vasıtasının hasara uğramasından dolayı mes'uliyetinin söz konusu olabilmesi için kamping meydanına bağlı bir garaj işletmesinin mevcudiyeti ve vasıtanın bu garaja tevdi edilmiș olması şarttır. Aksi halde kamping meydanın bekleyen bir bekçi dolayısıyla kamping idaresinin akdî mes'uliyeti yokṣa, vasıtanın hasarndan da kamping idaresi, otomobil yolcunun beraberinde getirdiği bir eşya olmasına rağmen bir barındırma akdi olmadığından mes'ul olmaz.

2 - Bazı hallerde kamping yerleri turiste çadır veya baraka tahsis etmektedirler. Bu takdirde kanaatimce edimin niteliği asgarî olmakla beraber bir otelcilik mukavelesi mevcutur. Imre böyle asgarî şartlar altında yapılan bir otelcilik mukavelesi olarak gayet cüz'i bir ücret mukabilinde hamamlarda gecelemeyi zikretmekte ve bu gibi hallerde hamamcllığın yanı sıra otelciliğe müșabih bir iş yapıldığından BK. 478 in tatbikini caiz görmektedir (14). Bu gö-

(14) İmre, agy. Sh. 196 
rüş kabul edilirse, BK. 478 böyle bir kamping mukavelesine de evleviyetle tatbik edilebilir. Nitekim Koblenz OLG de yukardan beri gözönünde bulundurduğumuz kararında müsbet bir hal tarzına bağlamamakla beraber, meseleye temas etmeden geçememiştir. Bir otelcilik mukavelesinin mevcudiyeti kabul edildiği andan iti. baren mes'uliyetin şartları eşyanın, turistin beraberinde gelmiș olması ve bir eşyanın kamping yerinde çalınması, hasara uğraması veya telef olmasidir.

Mes'uliyetin mahiyeti üzerinde ayrıca durmayı lüzumsuz addediyoruz. Çünki mes'uliyetin mahiyeti, gerek umumî eserlerdeki açıklamalarla, gerek bu husustaki münferit çalıșmalarla yeterli bir açılı̆̆a kavuşmuştur (15).

(15) Imre, agy ve Tandoğan, agm. Sh. 201 ve dev. 